\title{
KEMAMPUAN PENALARAN STATISTIKA: PENERAPAN MODEL PEMBELAJARAN LC7E DAN PENILAIAN AUTENTIK
}

\author{
Nopita Sari \\ Universitas Negeri Jakarta
}

\section{Wardani Rahayu}

FMIPA Universitas Negeri Jakarta, Jakarta Timur

\author{
Alamat Korespondensi \\ J. Pemuda 2, No. 17, \\ Rawamangun, \\ Jakarta Timur, DKI Jakarta \\ Indonesia \\ e-mail: \\ sarievitta@gmail.com
}

\begin{abstract}
This study aims to determine the effect of LC7e learning model and authentic assessment of students' statistical reasoning abilities. The sample in this research is the fourth semester student of PAI FTIK IAIN Pontianak. The dependent variable is statistical reasoning ability, and the independent variables consist of the differentiated learning model being LC7e and conventional, and the authentic judgements are differentiated into portfolios and written tests. The instrument used is a test of students' statistical reasoning abilities. The method used is quasi-experimental method while the design used is treatment by $2 \times 2$ design. The data obtained were analyzed by using two-way analysis of variance (ANAVA). The results of this study indicate that the students' statistical reasoning abilities using the LC7e model will be more effective if given a portfolio assessment. And students' statistical reasoning abilities using conventional models would be more effective if given a written test assessment
\end{abstract}

\section{Keywords}

LC7e Model, Authentic Assessment, Student Statistics Reasoning Skills

\section{ABSTRAK}

Penelitian ini bertujuan untuk mengetahui pengaruh model pembelajaran LC7e dan penilaian autentik terhadap kemampuan penalaran statistika mahasiswa. Sampel dalam penelitian ini adalah mahasiswa semester IV Jurusan PAI FTIK IAIN Pontianak. Variabel terikat berupa kemampuan penalaran statistika, dan variabel bebas terdiri dari model pembelajaran dibedakan menjadi LC7e dan konvensional, serta penilaian autentik dibedakan menjadi portofolio dan tes tertulis. Instrumen yang digunakan adalah tes kemampuan penalaran statistika mahasiswa. Metode yang digunakan adalah metode kuasi eksperimen sedangkan desain yang digunakan adalah treatment by desain $2 \times 2$. Data yang diperoleh dianalisis dengan menggunakan analisis varians (ANAVA) dua jalan. Hasil penelitian ini menunjukkan bahwa kemampuan penalaran statistika mahasiswa yang menggunakan model LC7e akan lebih efektif jika diberi penilaian portofolio. dan kemampuan penalaran statistika mahasiswa yang menggunakan model konvensional akan lebih efektif jika diberi penilaian tes tertulis

\section{Kata kunci}

Model LC7e, Penilaian Autentik, Kemampuan Penalaran Statistika Mahasiswa 
Nopita Sari

Wardani Rahayu

\section{I.Pendahuluan}

Mata kuliah statistika merupakan mata kuliah wajib di semua program studi karena mata kuliah ini menjadi prasyarat penyusunan tugas akhir pada program sarjana (Strata I) di IAIN Pontianak (Hermansyah, 20l4). Fokus perkuliahan di perguruan tinggi adalah mengembangkan kemampuan penalaran statistika dari pada hanya menghafal definisi, rumus, dan prosedur. Penalaran statistika mampu menjelaskan dan memahami proses statistik secara keseluruhan, dan mampu menafsirkan keberadaan hasil analisis statistik.

Kemampuan penalaran menjadi salah satu kemampuan yang perlu mendapatkan perhatian khusus, karena selain memperkuat konsep statistika, penalaran juga dapat meningkatkan kemampuan pemahaman mahasiswa terhadap statistika (Tatang, 2009). Kemampuan penalaran statistika merupakan kemampuan mahasiswa dalam menggunakan ide-ide statistika yang melibatkan hubungan atau konsep lain dengan konsep lain agar dapat memberikan penjelasan dan menarik suatu kesimpulan yang logis (Garfield, 2002; Karman lanani, 20I5; Shau Wei Chan dan Zaleha Ismail, 20I4; T. Dick, H. Winn, dan Sybrand Schim, 2006). Oleh karena itu kemampuan penalaran mahasiswa perlu dilatih dalam perkuliahan statistika.

Jurusan Pendidikan Agama Islam (PAI) Fakultas Tarbiyah dan Ilmu Keguruan (FTIK) Institut Agama Islam Negeri (IAIN) Pontianak ada sebanyak $75 \%$ mahasiswa yang tidak lulus pada mata kuliah statistika. Hal ini mengindikasikan bahwa kemampuan penalaran mahasiswa pada mata kuliah statistika belum memadai.

Faktor yang menyebabkan kemampuan penalaran statistika mahasiswa yang rendah antara lain pembelajaran yang masih didominasi oleh dosen. Dosen masih menggunakan metode ceramah dalam pembelajaran dan berperan penting untuk menentukan isi serta urutan langkah dalam penyampaian materi. Akibatnya pembelajaran kurang menarik minat belajar mahasiswa. Penilaian yang dilakukan dosen hanya bertumpu pada penilaian akhir seperti penilaian sumatif, tidak pada penilaian yang mencakup beberapa kompetensi yang harus dikuasai oleh mahasiswa. Faktor lainnya yaitu: mahasiswa bersifat pasif. Mahasiswa hanya mendengar dan mencatat pokok-pokok penting yang disampaikan dosen. Mahasiswa mudah jenuh, kurang inisiatif dan bergantung pada dosen, mahasiswa kurang mampu bernalar dalam mengerjakan soal. Akibatnya kemampuan bernalar mahasiswa masih rendah.

Penalaran statistika dapat berkembang melalui pendekatan, model, dan penilaian (Garfield, 2002; Lovett, 200I; Shiau Wei, Zahela, dan Bambang, 20I5). Salah satu alternatif untuk meningkatkan kemampuan penalaran, yaitu: dengan pemilihan model pembelajaran yang tepat. Ada banyak model pembelajaran diantaranya model pembelajaran LC7e. Model Learning Cycle 7e memiliki 7 tahapan siklus belajar, yaitu: Fase elicit, engage, explore, explain, elaborate, extend, dan evaluate (Eisenkraft, 2003; Khaled Khashan, 2016). Keuntungan dari model LC7e adalah dapat membantu mahasiswa memperoleh konsep dan menerapkannya dalam konteks baru dan situasi nyata, dapat mengembangkan keterampilan belajar mahasiswa, dapat memperbaiki kemampuan mahasiswa (memecahkan masalah, mengembangkan keterampilan dialog, dan semangat kerja kelompok/tim mahasiswa), dapat membantu mahasiswa untuk mengubah pandangan mahasiswa pada konsep yang terkait pada topik pembelajaran (Einskraft, 2003; Khaled Khashan, 2016) 
Nopita Sari

Wardani Rahayu
Selain model pembelajaran LC7e kemampuan penalaran juga dapat ditingkatkan melalui teknik penilaian. Adapun teknik penilaian yang digunakan adalah penilaian autentik, penilaian autentik merupakan penilaian yang mengacu pada penggunaan, pengajaran, dan penilaian yang mencerminkan tugas dunia nyata (Shelley Keyser, 2008; Robyn Collins, 2013; Anthony, 2005; Anna Maria, 2014). Karakteristik dari penilaian autentik adalah mahasiswa dapat mengidentifikasi masalah dari konteks mereka sendiri, mahasiswa berencana untuk memecahkan masalah mereka sendiri, eksplorasi dalam konteks nyata untuk menemukan solusi untuk masalah dan demonstrasi pemahaman dan solusinya kepada masyarakat (Sher Azim dan Mohammad Khan, 2012; Shelley Keyser, 2008).

Penelitian yang telah dilakukan oleh Shiau Wei dkk (2015) terkait penalaran statistika menggunakan model SRLE mengungkapkan bahwa penalaran statistik kelompok eksperimen lebih baik dari pada kelompok kontrol. Sejalan dengan penelitian mengenai kemampuan penalaran statistika, self-efficasy dan nilai keyakinan dalam course universitas statistik yang telah dilakukan oleh Olani dkk (20II) mengungkapkan bahwa siswa dapat mencapai konten terkait tujuan tentu saja penting dalam statistik direformasi terlepas dari latar belakang matematika mereka. Pencapaian tujuan pembelajaran tidak hanya dipengaruhi oleh diri dan nilai keyakinan tentang statistik melainkan rentan juga terhadap dukungan guru dan dorongan lain.

Sementara pada penelitian tentang penerapan model pembelajaran LC7e yang telah dilakukan oleh Abdul Kadir dan Ahmet (2013) dalam mengajarkan trigonometri menunjukkan bahwa skor prestasi akademis dan keabadian pengetahuan trigonometri siswa pada kelompok eksperimen lebih tinggi dari mereka yang berada dalam kelompok kontrol. Perbedaan yang terjadi di antara kedua kelompok tersebut signifikan secara statistik. Menurut Muhammad Naqeeb (2015) yang meneliti peningkatan prestasi siswa dalam pembelajaran biologi dengan menggunakan model LC7e mengungkapkan bahwa model pembelajaran LC7e lebih efektif dari pada pembelajaran tradisional dalam hal pencapaian peningkatan prestasi siswa.

\section{Metode Penelitian}

Penelitian ini menggunakan metode kuasi eksperimen dengan desain faktorial $2 \times 2$ dengan variabel terikatnya berupa kemampuan penalaran statistika mahasiswa, variabel bebas pertama berupa model pembelajaran terdiri dari LC7e dan konvensional, dan variabel bebas kedua penilaian autentik terdiri dari portofolio dan tes tertulis. Populasi dalam penelitian ini adalah seluruh mahasiswa Jurusan PAI FTIK IAIN Pontianak. Sampel dalam penelitian ini adalah mahasiswa semester IV terdiri dari empat kelas Tahun Ajaran 2017/2018. Tempat penelitian dilakukan di IAIN Pontianak. Instrumen yang digunakan adalah tes kemampuan penalaran statistika mahasiswa dengan dilakukan uji validitas dan reliabilitas.

\section{Pembahasan dan Hasil}

Hasil analisis deskripsi diperoleh rata-rata kemampuan penalaran statistika mahasiswa yang menggunakan model pembelajaran LC7e $\left(A_{I}\right)$ lebih baik dibandingkan dengan model pembelajaran konvesional $\left(\mathrm{A}_{2}\right)$. Kemampuan penalaran statistika mahasiswa yang diberi penilaian portofolio $\left(B_{\mid}\right)$ lebih baik dari kemampuan penalaran statistika mahasiswa yang diberi penilaian tes tertulis $\left(B_{2}\right)$. Sebaran data kemampuan penalaran statistika dengan model pembelajaran konvensional $\left(A_{2}\right)$ 
lebih homogen dibandingkan dengan sebaran data kemampuan penalaran dengan model pembelajaran LC7E $\left(A_{l}\right)$. Sebaran data kemampuan penalaran dengan penilaian tertulis $\left(B_{2}\right)$ lebih homogen dibandingkan sebaran data kemampuan penalaran dengan penilaian portofolio $\left(\mathrm{B}_{\mathrm{I}}\right)$

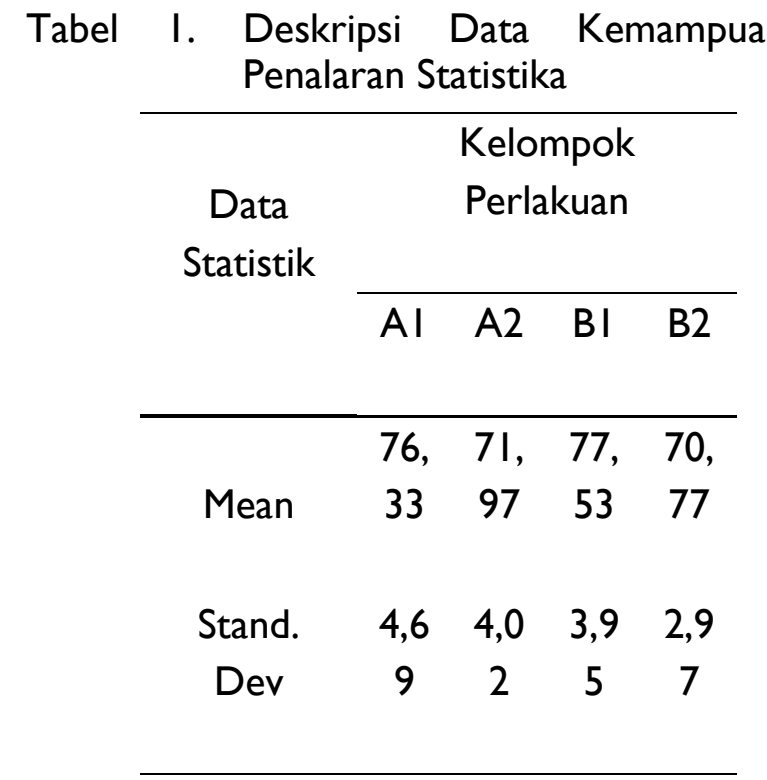

Kelompok mahasiswa yang menggunakan model pembelajaran LC7e dan penilaian portofolio $\left(A_{\mid} B_{\mid}\right)$, nilai median tidak terletak di tengah kotak dan garis whisker atas dan bawah sama panjang. Hal ini berarti bahwa bentuk distribusi skor kemampuan penalaran statistika mahasiswa kelompok $\left(A_{\mid} B_{\mid}\right)$simetris. Sementara pada kelompok mahasiswa yang menggunakan model pembelajaran LC7e dan penilaian tes tertulis $\left(A_{\mid} B_{2}\right)$, nilai median tidak terletak di tengah kotak dan garis whisker atas lebih panjang dari garis whiskes bawah. Hal ini berarti bahwa bentuk distribusi skor kemampuan penalaran statistika mahasiswa kelompok $\mathrm{A}_{\mid} \mathrm{B}_{2}$ skines positif. Sementara pada kelompok mahasiswa yang menggunakan model pembelajaran konvensional dan penilaian portofolio $\left(A_{2} B_{\mid}\right)$, nilai median tidak terletak di tengah kotak dan garis whisker atas lebih panjang dari garis whisker bawah. Hal ini berarti bahwa bentuk distribusi skor kemampuan penalaran statistika mahasiswa kelompok $A_{2} B_{1}$ skines positif. Sementara pada kelompok mahasiswa yang menggunakan model pembelajaran konvensional dan penilaian tes tertulis $\left(A_{2} B_{2}\right)$, nilai median tidak terletak di tengah kotak dan garis whisker atas lebih panjang dari garis whisker bawah. Hal ini berarti bahwa bentuk distribusi skor kemampuan penalaran statistika mahasiswa kelompok $A_{2} B_{2}$ skines positif.

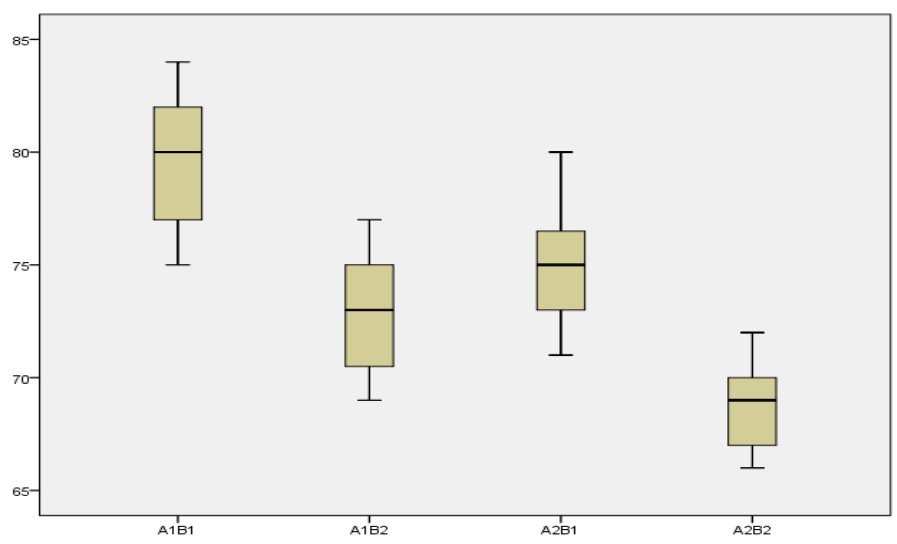

Gambar I. Kemampuan penalaran untuk setiap perlakuan

Hasil analisis main effect diperoleh pada taraf signifikansi $\alpha=0,05$ menunjukkan bahwa p.value kurang dari 0,05, sehingga dapat diambil kesimpulan kemampuan penalaran statistika mahasiswa pada kelompok yang menggunakan model pembelajaran LC7e lebih tinggi dari pada kemampuan penalaran statistika mahasiswa yang menggunakan model pembelajaran konvensional, kemampuan penalaran statistika mahasiswa pada kelompok yang diberi penilaian portofolio lebih tinggi dari pada mahasiswa yang diberi penilaian tes tertulis, dan terdapat pengaruh interaksi antara model 
Nopita Sari

Wardani Rahayu pembelajaran LC7e dan penilaian autentik terhadap kemampuan penalaran statistika.

Hasil analisis simple effect pada taraf signifikansi $\alpha=0,05$ menunjukkan bahwa thitung lebih dari $t_{\text {tabel, }}$, sehingga dapat diambil kesimpulan bahwa mahasiswa yang diajar menggunakan model pembelajaran LC7e dengan penilaian portofolio lebih tinggi dari kelompok mahasiswa yang diajar menggunakan model pembelajaran konvensional dengan penilaian portofolio. Kemampuan penalaran mahasiswa yang diajar menggunakan model pembelajaran LC7e dengan penilaian tes tertulis lebih rendah dari kelompok mahasiswa yang diajar menggunakan model pembelajaran konvensional dengan penilaian tes tertulis. Kemampuan penalaran mahasiswa yang diajar menggunakan model pembelajaran LC7e dengan penilaian portofolio lebih tinggi dari kelompok mahasiswa yang diajar menggunakan model pembelajaran LC7e dengan penilaian tes tertulis. Kemampuan penalaran mahasiswa yang diajar dengan model pembelajaran konvensional dengan penilaian portofolio lebih rendah dari kelompok mahasiswa yang diajar menggunakan model konvensional dengan penilaian tes tertulis.

Hasil penelitian ini menunjukkan bahwa kemampuan penalaran statistika mahasiswa yang menggunakan model pembelajaran LC7e lebih tinggi dibandingkan dengan menggunakan model konvensional. Model pembelajaran LC7e dapat memberikan kesempatan pada mahasiswa untuk membangun pengetahuannya sendiri sehingga kemampuan berpikir mahasiswa dapat berkembang secara maksimal. Mahasiswa dapat membangun pengetahuannya sendiri melalui tujuh tahapan pembelajaran yang ada pada model LC7e terutama para tahap explore. Pada tahap explore mahasiswa diberi kesempatan untuk membangun pengetahuannya secara berkelompok. Kegiatan secara berkelompok dapat membuat interaksi sosial yang baik di antara mahasiswa untuk menyelesaikan soal penalaran statistika yang diberikan.

Di dalam penelitian ini, model pembelajaran LC7e yang dirancang melalui tujuh tahapan pembelajaran, yakni pada awal pembelajaran dosen menanyakan kesiapan mahasiswa untuk menerima pembelajaran serta menyampaikan tujuan pembelajaran. Pada tahap Elicit mahasiswa sangat antusias dalam tahap ini untuk menyebutkan contoh-contoh materi yang sedang dipelajari (derajat pengukuran dan ukuran pemusatan data) yang sering dijumpai dalam kehidupan sehari-hari. Pada tahap Engange dosen bercerita tentang suatu fenomena yang sering terjadi dalam kehidupan sehari-hari dan memberikan pertanyaan kepada mahasiswa tentang cerita tersebut untuk merangsang dan membangkitkan minat mahasiswa. Pada tahap ini mahasiswa terlihat kebingungan dan tidak banyak mahasiswa yang dapat menjawab pertanyaan dari dosen tersebut. Pada tahap Explore mahasiswa dibagi dalam beberapa kelompok dan diberikan LKM yang didalamnya terdapat beberapa tahapan untuk menentukan derajat pengukuran dan ukuran pemusatan datanya. Pada tahap ini mahasiswa terlibat aktif dalam proses pembelajaran walaupun mahasiswa masih terlihat bingung tetapi mahasiswa berusaha mengerjakan LKM dengan bertanya kepada dosen. Pada tahap Explan mahasiswa diminta untuk menjelaskan hasil diskusi bersama dengan teman sekelompoknya. Pada pertemuan pertama mahasiswa masih terlihat kurang percaya diri dalam mempresentasikan hasil kerja kelompoknya, tetapi pada pertemuan selanjutnya mahasiswa mulai terbiasa jika diminta 
Nopita Sari

Wardani Rahayu untuk mempresentasikan hasil kerja kelompoknya. Pada tahap Evaluate dosen menilai kerja mahasiswa secara kelompok dan individu pada tahap Elaborate, sehingga mahasiswa sangat antusias dalam mengerjakan tugas yang ada di LKM tersebut pada tahap Elaborate. Pada tahap Extend dosen meminta mahasiswa mendiskusikan penerapan konsep tersebut dalam kehidupan sehari-hari dan menawarkan kepada mahasiswa untuk mempresentasikan hasil diskusinya. Pada tahap ini mahasiswa antusias untuk mempresentasikan hasil diskusinya mengenai penerapan konsep dalam kehidupan sehari-hari.

Hal ini didukung pula oleh Muhammad Naqeeb (20I5) yang menyatakan bahwa fokus pada tahapan elicit adalah membuat siswa dapat meninjau kembali pengalaman sebelumnya terkait dengan situasi belajar yang mereka hadapi saat ini, sehingga dapat meningkatkan perhatian mereka untuk siap belajar dan memotivasi mereka untuk membangun pengetahuan mereka sendiri. Fokus pada tahap explore adalah menciptakan lingkungan belajar bagi siswa yang melakukan observasi dan mengembangkan pengetahuan, mencatat data, agar terdapat interaksi dengan siswa yang lain, dan peran guru adalah sebagai fasilitator yang hanya memberikan pertanyaan, memberikan informasi, memberi umpan balik, dan mengukur tingkat pemahaman siswa. Fokus pada tahap elaborate membantu siswa dalam mengimplementasikan pengetahuan yang didapat di masa lalu ketika mereka menemukan situasi baru, siswa diberikan pemahaman dan keterampilan untuk mengerjakan tugas yang telah ditetapkan untuk tahap evaluasi.

Model LC7e ini memberikan peluang yang besar kepada mahasiswa untuk mengembangkan diri menjadi lebih aktif dalam membangun pengetahuan belajarnya, sehingga akan memberikan pengaruh positif terhadap kemampuan penalaran statistikanya. Model pembelajaran konvensional juga memiliki beberapa kelebihan dan kekurangan, namun model pembelajaran konvensional yang umumnya berpusat pada dosen sebagai narasumber utama proses pembelajaran, sering mengakibatkan mahasiswa kurang aktif sehingga menimbulkan kejenuhan pada diri mahasiswa dalam mengikuti proses pembelajaran, kurang termotivasi dalam belajar dan hal ini pada akhirnya mempengaruhi kemampuan penalaran mahasiswa, penelitian ini membuktikan kemampuan penalaran statistika mahasiswa yang diajar dengan model pembelajaran LC7e lebih tinggi dibandingkan dengan model pembelajaran konvensional.

Hasil penelitian selanjutnya menunjukkan bahwa kemampuan penalaran statistika mahasiswa yang diberi penilaian portofolio lebih tinggi dibandingkan kelompok mahasiswa yang diberi penilaian tes tertulis. Kenyataan ini membuktikan bahwa penilaian portofolio lebih baik dalam meningkatkan kemampuan penalaran mahasiswa dibandingkan dengan penilaian tes tertulis. Hal ini didukung oleh penelitian yang dilakukan oleh Galuh Rahmawati, dkk (2013) yang menyatakan bahwa hasil analisis angket menyatakan bahwa respon siswa terhadap pelaksanaan penilaian portofolio 75\% dan siswa berharap portofolio diterapkan dalam mata pelajaran lain $67 \%$. Oleh karena itu dapat dinyatakan bahwa penerapan penilaian portofolio berpengaruh positif terhadap hasil belajar siswa.

Selanjutnya Mahvan Ebrahimzadeh (2016) yang menyatakan bahwa Penilaian portofolio dianggap sebagai salah satu penilaian alternatif paling populer, karena didasarkan pada prosedur penilaian yang sistematis dapat memberikan informasi yang berguna dan akurat tentang 
Nopita Sari

Wardani Rahayu kedalaman dan keluasan kemampuan siswa dalam berbagai aspek penilaian. Penilaian portofolio memberikan data yang lebih handal dan dinamis tentang siswa untuk guru, orang tua, dan juga siswa sendiri. Selain itu, dengan menggunakan metode penilaian ini, dapat meningkatkan otonomi siswa dan berpikir kritis siswa serta memberikan informasi yang jelas tentang perkembangan siswa, baik dari kemajuan belajar siswa, prestasi siswa, maupun kelemahannya, agar dapat membantu guru merencanakan kemajuan mengajar selanjutnya.

Penilaian dengan portofolio merupakan penilaian yang menuntut mahasiswa untuk mendemonstrasikan pengetahuan dan keterampilan yang sudah dipelajari dalam bentuk karya nyata, dan merupakan penilaian terhadap koleksi pekerjaan mahasiswa dalam rangka menunjukkan perkembangan belajar dan perbuatan melalui refleksi diri dan prestasi. Pelaksanaan penilaian portofolio menyertakan mahasiswa dalam menilai kemajuan belajarnya atau prestasinya. Dengan menyertakan mahasiswa dalam menilai kemajuan belajarnya sendiri, mahasiswa menjadi lebih mengerti, sadar diri akan kemampuannya. Dengan penilaian ini mahasiswa mempunyai motivasi yang tinggi untuk menyelesaikan tugas-tugas secara sempurna.

Hal yang lebih baik pada penilaian portofolio adalah dapat mengukur prestasi tiap siswa dengan memperhatikan perbedaan individu antar mahasiswa. Dengan demikian setiap mahasiswa merasa diperlakukan secara adil dan mendapatkan layanan secara individual sesuai dengan kemampuan setiap mahasiswa. Penilaian portofolio dapat memberikan suasana yang akrab, saling terbuka antara dosen dan mahasiswa, karena penilaian ini mengutamakan prinsip penilaian dengan pendekatan yang kolaboratif antara dosen dan mahasiswa.
Mahasiswa diberikan kesempatan untuk menilai karya atau tugasnya sendiri dengan menggunakan rambu-rambu yang telah ditentukan. Dosen hanya mengarahkan mahasiswa untuk dapat menilai secara benar dengan menggunakan rambu-rambu tersebut. Selanjutnya dosen dan mahasiswa berdiskusi dan mencocokkan satu persatu untuk mendapatkan keselarasan penilaian sesuai dengan rambu-rambu dan kaidah penyelesaian soal yang benar. Dengan demikian hasil penilaian atas karya/ tugas mahasiswa dapat diterima secara bersama antara dosen dan mahasiswa.

Penilaian portofolio merupakan jenis penilaian yang komprehensif, terstruktur dan dapat meningkatkan kemampuan penalaran statistika mahasiswa dalam menyelesaikan tugas-tugas berbentuk portofolio secara maksimal. Penilaian ini sangat cocok untuk dapat mengungkapkan seluruh kemampuan mahasiswa yang tidak dapat diungkapkan dengan penilaian tes tertulis. Penilaian dengan menggunakan tes tertulis dapat membuat peserta tes cenderung hanya mengandalkan kemampuan kognitif tanpa melibatkan kemampuan yang lain. Penilaian dengan menggunakan tes tertulis kurang mampu mengukur penalaran statistika dengan baik. Hal ini disebabkan penalaran statistika membutuhkan pemikiran yang logis, kritis, dan analisis sehingga dibutuhkan proses penilaian yang lebih kompleks. Dengan hal itu tentu saja kemampuan penalaran statistika mahasiswa yang dinilai dengan portofolio akan lebih tinggi dari pada kemampuan penalaran statistika mahasiswa yang dinilai dengan tes tertulis.

Hasil penelitian selanjutnya menunjukkan bahwa terdapat pengaruh interaksi antara model pembelajaran LC7e dan penilaian autentik terhadap kemampuan penalaran statistika. Penggunaan model pembelajaran LC7e pada proses pembelajaran 
Nopita Sari

Wardani Rahayu dapat mempengaruhi kemampuan penalaran statistika mahasiswa, perbedaan kemampuan penalaran statistika disebabkan adanya karakteristik khas pada setiap model pembelajaran yang digunakan. Apabila model pembelajaran yang digunakan sama dan penilaian yang diberikan berbeda maka kemampuan penalaran statistika mahasiswa akan berbeda. Perbedaan kemampuan ini disesuaikan dengan karakteristik model pembelajaran dan penilaian. Dari hasil analisis data di atas dapat dijelaskan bahwa, dalam menciptakan suasana dan proses pembelajaran yang berkualitas maka perlu ditunjang oleh beberapa komponen seperti, penerapan model pembelajaran, metode, media, iklim, kelas, dan sebagainya. Faktor eksternal ini jika dioptimalkan secara baik akan memberikan kontribusi yang positif terhadap kualitas pembelajaran. Seperti halnya penerapan model pembelajaran, tentu pemilihan model pembelajaran tidak dapat dilakukan begitu saja. Akan tetapi, mempertimbangkan aspek tujuan maupun kesesuaian dengan materi kuliah. Karena tidak semua model pembelajaran akan cocok dengan mata kuliah tertentu. Selain itu, untuk mempertahankan mutu pembelajaran maka dosen dalam hal ini juga perlu memberikan evaluasi, baik yang sifatnya formatif maupun sumatif. Dengan tujuan untuk mengetahui sejauh mana pencapaian hasil belajar mahasiswa. Dari temuan ini dapat diketahui bahwa, dengan menerapkan model pembelajaran yang tepat dan dengan memperhatikan frekuensi pemberian tes secara intensif memberikan pengaruh yang positif terhadap kemampuan penalaran statistika mahasiswa.

Hasil penelitian selanjutnya menunjukkan bahwa kemampuan penalaran statistika mahasiswa yang diajar menggunakan model pembelajaran LC7e lebih tinggi dibanding dengan mahasiswa yang diajar menggunakan model konvensional. Hal ini dapat terjadi karena karakteristik model pembelajaran LC7e dalam pembelajaran statistika sesuai dengan karakteristik mahasiswa dengan penilaian portofolio. Penilaian portofolio dilakukan mulai dari perencanaan, proses pengerjaan, sampai hasil akhir. Untuk itu dosen perlu menetapkan hal-hal atau tahapan yang perlu dinilai, seperti pengumpulan data, analisis data, dan penyajian data, serta penyiapan laporan tertulis.

Manfaat dalam pembelajaran LC7e adalah memungkinkan mahasiswa menemukan sendiri informasi-informasi yang diperlukan untuk mencapai tujuan belajarnya, karena model pembelajaran LC7e melibatkan mahasiswa untuk aktif dalam kelas selama proses pembelajaran. Apabila model pembelajaran LC7e diterapkan pada penilaian portofolio diperlukan mahasiswa untuk mendemonstrasikan keterampilan dalam bentuk karya nyata setelah proses pembelajaran. Hal ini didukung oleh Balta dan Sarac (2016) menyatakan bahwa model LC7e yang mengacu pada teori belajar konstruktivisme mengharuskan siswa untuk aktif dalam kelas selama proses pembelajaran, dan merupakan suatu pendekatan yang membantu siswa memperoleh pengetahuan baru dengan menggunakan pengetahuan sebelumnya. Sedangkan menurut Ahmad Syarifi (20II) menyatakan bahwa berdasarkan teori konstruktivis yang menganjurkan bahwa pembelajaran harus dibagun oleh peserta didik itu sendiri, dari pada diberikan oleh guru. Penilaian portofolio menuntut siswa untuk mendemonstrasikan dalam bentuk karya nyata. Dengan kesesuaian karakteristik model LC7e dan penilaian portofolio dapat dipastikan bahwa kemampuan penalaran statistika mahasiswa yang diajar menggunakan model pembelajaran LC7e 
Nopita Sari

Wardani Rahayu lebih tinggi dibanding dengan mahasiswa yang diajar menggunakan model konvensional.

Hasil penelitian selanjutnya menunjukkan bahwa kemampuan penalaran statistika mahasiswa yang diajarkan dengan model pembelajaran LC7e lebih rendah dibanding mahasiswa yang diajar dengan model konvensional. Penggunaan penilaian portofolio dalam proses pembelajaran lebih efektif dibandingkan penilaian tes tertulis apabila menggunakan model pembelajaran LC7e. Manfaat pada penilaian portofolio adalah untuk menyesuaikan dalam proses pembelajaran, keputusan hasil belajar akan dapat memberikan kesempatan belajar yang adil, sehingga mahasiswa dapat memperbaiki metode belajarnya. Hal ini akan berdampak pada perbaikan perencanaan dan pengembangan dalam proses pembelajaran untuk menghadapi tantangan masa depan. Apabila penilaian dipadukan dengan model pembelajaran yang sesuai maka akan dapat meningkatkan kemampuan penalaran statistika mahasiswa.

Pemberian tes tertulis memungkinkan penggunaan model pembelajaran LC7e kurang maksimal, mengingat bahwa penilaian tes tertulis cenderung hanya mengandalkan kemampuan kognitif tanpa melibatkan kemampuan yang lain. Penggunaan model pembelajaran konvensional dirasa lebih baik, karena pada proses pembelajarannya hanya terpaku pada dosen. Dalam pembelajaran konvensional, mahasiswa umumnya memperoleh pengetahuan dari informasi yang disampaikan oleh dosen, bukan dari sikap dan keterampilan yang dibentuk/dilatihkan kepada mereka. Hal ini didukung oleh Balta dan Sarac (2016) menyatakan bahwa model LC7e yang mengacu pada teori belajar konstruktivisme mengharuskan siswa untuk aktif dalam kelas selama proses pembelajaran, dan merupakan suatu pendekatan yang membantu siswa memperoleh pengetahuan baru dengan menggunakan pengetahuan sebelumnya. Sedangkan menurut Muhammad Naqeeb (2015) menyatakan bahwa model pembelajaran konvensional peserta didik secara pasif memperoleh pengetahuan yang hanya disediakan oleh guru. Hal ini membuktikan untuk mahasiswa yang dinilai dengan tes tertulis. Kemampuan penalaran statistika mahasiswa yang diajarkan dengan model pembelajaran LC7e lebih rendah dibanding mahasiswa yang diajar dengan model konvensional.

Hasil penelitian selanjutnya menunjukkan bahwa kemampuan penalaran statistika mahasiswa dengan penilaian portofolio lebih tinggi dibandingkan dengan penilaian tes tertulis. Penggunaan penilaian portofolio dalam proses pembelajaran memberi kesempatan kepada mahasiswa untuk lebih memahami berbagai keterampilan yang dipelajari. Penilaian portofolio penting dilakukan oleh dosen karena selain merupakan satu penilaian alternatif, penilaian portofolio juga dapat menilai pengetahuan dan juga keterampilan mahasiswa. Hal ini didukung oleh Mahvan Ebrahimzadeh (2016) yang menyatakan bahwa Penilaian portofolio dianggap sebagai salah satu penilaian alternatif paling populer, karena didasarkan pada prosedur penilaian yang sistematis dapat memberikan informasi yang berguna dan akurat tentang kedalaman dan keluasan kemampuan siswa dalam berbagai aspek penilaian. Penilaian portofolio dirancang untuk menilaian kemampuan pengetahuan dan keterampilan mahasiswa. Di dalam penilaian portofolio dosen dapat mengetahui kemampuan mahasiswa selama proses pembelajaran berlangsung.

Penggunaan model pembelajaran LC7e dalam pembelajaran statistika, banyak melibatkan aktivitas 
Nopita Sari

Wardani Rahayu mahasiswa melalui tujuh tahapan pembelajarannya, sehingga mahasiswa akan menjadi lebih aktif dalam proses pembelajaran tersebut. Hal ini didukung oleh Balta dan Sarac (2016) menyatakan bahwa model LC7e yang mengacu pada teori belajar konstruktivisme mengharuskan siswa untuk aktif dalam kelas selama proses pembelajaran, dan merupakan suatu pendekatan yang membantu siswa memperoleh pengetahuan baru dengan menggunakan pengetahuan sebelumnya. Jika dikaitkan model pembelajaran LC7e dan penilaian portofolio dari kedua pendapat di atas, maka keduanya sama-sama menuntut mahasiswa untuk aktif dalam pembelajaran, sehingga dapat meningkatkan kemampuan penalaran statistika mahasiswa. Hal ini membuktikan untuk model pembelajaran LC7e, kemampuan penalaran statistika mahasiswa dengan penilaian portofolio lebih tinggi dibandingkan dengan penilaian tes tertulis.

Hasil penelitian selanjutnya menunjukkan bahwa kemampuan penalaran statistika mahasiswa yang menggunakan dengan model pembelajaran konvensional dan penilaian portofolio lebih rendah dibandingkan dengan penilaian tes tertulis. Hal ini dapat terjadi karena dalam penilaian dengan portofolio menuntut mahasiswa untuk mendemonstrasikan pengetahuan dan keterampilan yang sudah dipelajari dalam bentuk karya nyata, sedangkan model konvensional proses pembelajarannya hanya terpaku pada dosen Dalam pembelajaran konvensional, mahasiswa umumnya memperoleh pengetahuan dari informasi yang disampaikan oleh dosen, bukan dari sikap dan keterampilan yang dibentuk/dilatihkan kepada mereka, model konvensional dirasa sesuai dengan penilaian tes tertulis yang merupakan suatu teknik penilaian yang efektif untuk menilai pengetahuan.

Hal ini didukung oleh Mahvan Ebrahimzadeh (2016) yang menyatakan bahwa penilaian portofolio dianggap sebagai salah satu penilaian alternatif paling populer, karena didasarkan pada prosedur penilaian yang sistematis dapat memberikan informasi yang berguna dan akurat tentang kedalaman dan keluasan kemampuan siswa dalam berbagai aspek penilaian. Penilaian portofolio dirancang untuk menilaian kemampuan pengetahuan dan keterampilan mahasiswa. Dalam penilaian portofolio dosen dapat mengetahui kemampuan mahasiswa selama proses pembelajaran berlangsung. Sedangkan menurut Muhammad Naqeeb (20I5) menyatakan bahwa model pembelajaran konvensional peserta didik secara pasif memperoleh pengetahuan yang hanya disediakan oleh guru. Hal ini membuktikan untuk mahasiswa yang diajar menggunakan model konvensional. Kemampuan penalaran statistika mahasiswa yang diberi penilaian Portofolio lebih rendah dibanding mahasiswa yang diberi penilaian tes tertulis.

\section{Kesimpulan}

Hasil penelitian ini menunjukkan bahwa model pembelajaran LC7e dan penilaian autentik pengaruh terhadap kemampuan penalaran statistika, kemampuan penalaran statistika mahasiswa yang menggunakan model LC7e akan lebih efektif jika diberi penilaian portofolio. dan kemampuan penalaran statistika mahasiswa yang menggunakan model konvensional akan lebih efektif jika diberi penilaian tes tertulis.

\section{Daftar Pustaka}


Abdul Kadir dkk,"The Effect of 5e Learning Cycle Model In Teaching Trigonometry on Students' Academic Achievement and The Permanence of Their Knowledge", International Journal on New Trends in Education and Their Implication, Vol. 4 (I), Spring 2013.

Anna Maria Bosco, "Embedding Authentic Assessment in Work-integrated Learning Curriculum," Asia Pacific Journal of Cooperative Education, Vol I5 (4), Spring 2014.

Anthony J. Onwuegbuzie, dan Nancy L. Leech. 2005. Assessment Program Statistics: Over Evaluation Tool. Denver: University of Colorado.

Balta dan Sarac, "The Effect of 7E Learning Cycle on Learning in Science Teaching: A meta-Analysis Study," European Journal of Educational Research, Vol. 5 (2), Spring 2016.

Eisenkraft, 2003. A. Expanding the 5E model: A Proposed 7E Model Emphazies "Transfer Learning" and The Importance of Eliciting Prior Understanding : Arlington: NSTA.

Hermansyah, dkk. 20I4. Pedoman Penulisan Skripsi IAIN Pontianak Pontianak: IAIN Pontianak Press.

Joan Garfield, "The Challenge of Developing Statistical Reasoning," Journal of Statistics Education, Vol. 10 (3), Spring 2002.

Khaled Khashan, "The Effectiveness of Using the 7E's Learning Cycle Strategy on the Immediate and Delayed Mathematics Achievement and the Longitudinal Impact of Learning among Preparatory Year Students at King Saud University (KSU)", Journal of Education and Practice, Vol. 7 (36), Spring 2016.
Lanani, Karman. "Kemampuan Penalaran Statistik, Komunikasi Statistik dan Academic Help-Seeking Mahasiswa dalam Pembelajaran Berbasis Proyek Berbantuan ICT," Jurnal Pendidikan UPI, Tahun 2015.

Lovett, 200I. "A collaborative convergence on learning the reasoning process: $A$ case study in statistics, Cognition and Instruction: Twenty Five Years of Progress", eds, D klahr and S, Carver, Marwah, NJ: Lawrence Erlbaum, 374.

Mahvan Ebrahimzadeh,"Portfolio Assessment as a Window into Reading Development," International Journal of Foreign Language Teaching and research, Vol. 4 (13), Spring 2016.

Muhammad Naqeeb UI Khalil Shaheen, “Improving Students' Achievement in Biology using 7E Instructional Model An Experimental Study", Mediterranean Journal of Social Sciences, Vol. 6 (4), Spring 2015.

Robyn Collins, "Authentic assessment: assessment for learning" An Electronic Journal for Leaders in Education, Vol. I I (7), Spring 2013.

Sher Azim, dkk, "Authentic Assessment: An Instructional Tool to Enhance Students Learning," Journal Academic Research International, Vol. 2 (3), Spring 2012.

Shelley Keyser, 2008, "The State of Authentic Assessment”, Master's Student-Department of Instructional Psychology and Technology, http://files.eric.ed.gov/fulltext/ED503679.pdf

Shiau Wei Chan, dkk, "A Statistical Reasoning Based Technology Assessment Tool Descriptive Statistics for High School Study The Impact of Statistical Reasoning Learning Environment: A Rasch Analysis," Journal 
American Scientific Publishers, Vol. 21 (5), Spring 2015. Doi: 10.1166/asl.2015.6077.

Tatang Yuli Eko Siswono, dkk, "Proses Berpikir Analogi Siswa dalam Memecahkan masalah Matematika Siswa," Jurnal Pendidikan Matematika FMIPA UNESA, Tahun 2009.

Olani, dkk, "Statistics of Reasoning Abilities, Self-Efficacy, and Values of Confidence in the Course of University of Statistics," Electronic Journal of Research in Educational Psychology, Vol. 9 (I), Spring 20II 